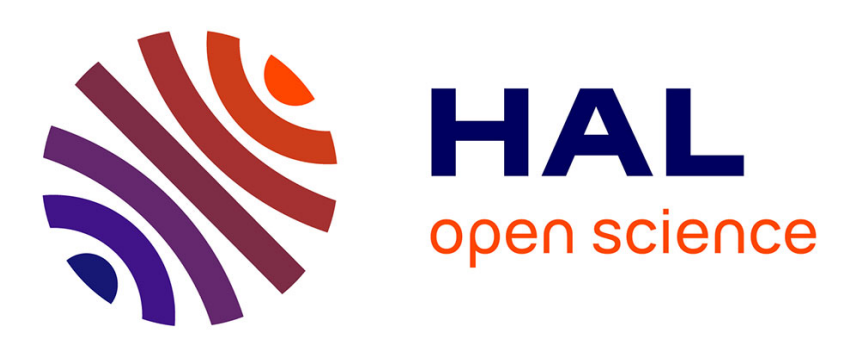

\title{
Isotope and molecular evidence for direct input of maize leaf wax n-alkanes into crop soils
}

\author{
Eric Lichtfouse, Brigitte Elbisser, Jérôme Balesdent, André A. Mariotti, \\ Gérard Bardoux
}

\section{- To cite this version:}

Eric Lichtfouse, Brigitte Elbisser, Jérôme Balesdent, André A. Mariotti, Gérard Bardoux. Isotope and molecular evidence for direct input of maize leaf wax n-alkanes into crop soils. Organic Geochemistry, 1994, 22 (2), pp.349-351. 10.1016/0146-6380(94)90181-3 . hal-00190969

\section{HAL Id: hal-00190969 \\ https://hal.science/hal-00190969}

Submitted on 26 Nov 2007

HAL is a multi-disciplinary open access archive for the deposit and dissemination of scientific research documents, whether they are published or not. The documents may come from teaching and research institutions in France or abroad, or from public or private research centers.
L'archive ouverte pluridisciplinaire HAL, est destinée au dépôt et à la diffusion de documents scientifiques de niveau recherche, publiés ou non, émanant des établissements d'enseignement et de recherche français ou étrangers, des laboratoires publics ou privés. 
Revised version

Organic Geochemistry 22, 349-351, 1994.

doi:10.1016/0146-6380(94)90181-3

\title{
Isotope and molecular evidence for direct input of maize leaf wax $n$-alkanes into crop soils
}

\section{É. LICHTFOUSE, ${ }^{1,2 *}$ B. ELBISSER, ${ }^{2}$ J. BALESDENT,$^{1}{ }^{\text {A. }}$ MARIOTTI ${ }^{1}$ and G. BARDOUX ${ }^{1}$}

${ }^{1}$ Laboratoire de Biogéochimie Isotopique, associé à l'Institut National de la Recherche Agronomique, Université Pierre et Marie Curie, Case 120, 75252 Paris Cedex 05 and 2 46, Boulevard de Reuilly, 75012 Paris, France.

\begin{abstract}
The contribution of plant carbon to crop soils can be followed by isotope labelling at natural abundance, such as growing a $\mathrm{C}_{4}$ plant on a soil which was previously under $\mathrm{C}_{3}$ vegetation. For this purpose, carbon isotope compositions and relative abundances of $n$-alkanes of maize leaf waxes and maize crop soils were compared. Isotope values of soil $n$-alkanes increased with time of maize cultivation as the result of maize carbon integration into soil organic matter. With increasing time of cultivation, the increase in isotopic difference between $n$-heptacosane $\left(\mathrm{C}_{27}\right)$ and $n$-nonacosane $\left(\mathrm{C}_{29}\right)$ is explained, at least partly, by a direct input of maize leaf $n$-alkanes. The amount of maize-derived carbon within each $n$-alkane has been calculated by isotopic means.
\end{abstract}

Key words - $n$-alkane, soil, plant, waxes, Zea mays, ${ }^{13} \mathrm{C}$.

\section{INTRODUCTION}

Distributions of sedimentary $n$-alkanes have been widely used for source identification in sediments. However, the specificity of $n$-alkanes as source parameters might be limited because our knowledge of biological $n$-alkanes, or their possible precursors, is relatively poor, especially among microorganisms, as reviewed by Collister et al., 1994a. For example, the distribution of $n$-alkenes from the alga Botryococcus Braunii (A race) with a strong predominance of oddcarbon number homologues in the range $\mathrm{C}_{27}$ to $\mathrm{C}_{33}$, is very close to $n$-alkane distributions in terrestrial plants (Lichtfouse et al., 1994a). Moreover, recent isotope studies have shown that extracted sedimentary $n$-alkanes can derive not only from higher plants $n$-alkanes but also from $n$-alkanoic acids (Lichtfouse and Collister, 1992) or from algal $n$-alkenes (Freeman et al., 1994, Collister et al., 1994a, Spooner et al., 1994, Lichtfouse et al., 1994a).

In soils, studies of possible sources of organic components seem more straightforward, as compared to sediments, because the input of phytoplankton is minor relative to the input of higher plants. However, numerous soil organisms are able to biosynthesize $n$-alkanes or their precursors (Kolattukudy, 1976, Dinel et al., 1990). For this reason, and also because food chain flows from plants to soil biomass are far from being understood, the direct input of leaf wax $n$ alkanes into soil is still to be proved. The fate of plant carbon into a soil can be followed by isotopic labelling in natural conditions. Hence, growing a $\mathrm{C}_{4}$ plant, maize (bulk $\delta^{13} \mathrm{C}-12 \%$ ) on a soil which was previously under $\mathrm{C}_{3}$ vegetation (bulk $\delta^{13} \mathrm{C}-26 \%$ ) can cause the isotopic composition of bulk soil organic matter to increase from $-26 \%$ o toward $-13 \%$ (Balesdent et al., 1987). Because leaf wax $n$-alkanes from $C_{3}$ plants and $C_{4}$ plants are also isotopically different (Rieley et al., 1991, 1993, Collister et al., 1994b, Lichtfouse et al., 1994a), the isotopic composition of soil $n$-alkanes should be related to their source. In this preliminary report, we

* corresponding author. Previous contributions: Org. Geochem. 21, 517 (1994), Tetrahedron 50, 1731 (1994). 
have evaluated the contribution of leaf wax $n$-alkanes to soil $n$-alkanes via molecular and isotope analysis.

\section{EXPERIMENTAL}

Detailed procedures will be described elsewhere (Lichtfouse, 1994). Zea mays was grown in an experimental field at La Minière, France, at one crop per year on a soil which has previously been cultivated only with $\mathrm{C}_{3}$ plants. Soils and Z. mays leaves were extracted with $\mathrm{CHCl}_{3}-\mathrm{MeOH} 3 / 1 \mathrm{v} / \mathrm{v}$. Alkane fractions were obtained from extracts by silica gel chromatography (Lichtfouse et al., 1994b). $n$-Alkanes were identified by gas chromatographymass spectrometry (GC-MS) and by co-elution of pure standards. Their purity (>99.9\%) was carefully checked by GC-MS and gas chromatography-combustion-isotope ratio mass spectrometry (GC-C-IRMS) in order to give accurate isotopic values (Lichtfouse et al., 1991). The overall deviation was $\pm 0.3 \%$. $n$-Alkane relative abundances (area/area) were determined by gas chromatography using a flame ionization detector. GC-C-IRMS conditions are given in Lichtfouse et al. (1994a). Carbon isotopic compositions are expressed in per mil. relative to the PDB standard: $\delta^{13} \mathrm{C}=\left[\left({ }^{13} \mathrm{C} /{ }^{12} \mathrm{C}\right.\right.$ sample $-{ }^{13} \mathrm{C} /{ }^{12} \mathrm{C}$ std $) /\left({ }^{13} \mathrm{C} /{ }^{12} \mathrm{C}\right.$ std $\left.)\right] \times 10^{3}$, where ${ }^{13} \mathrm{C} /{ }^{12} \mathrm{C}$ std $=0.0112372$.

\section{Initial isotope ratios}

\section{RESULTS AND DISCUSSION}

Carbon isotope compositions and relative abundances of selected $n$-alkanes from maize leaf waxes and maize crop soils are reported in Table 1. Before maize cropping, the soil was cultivated with $\mathrm{C}_{3}$ plants. Distributions of soil $n$-alkanes in the range $\mathrm{C}_{25}$ to $\mathrm{C}_{35}$ were very similar to those of higher plants, e.g. they display a strong odd-carbon number predominance (Lichtfouse, 1994). Before cultivation, the isotope compositions for $n$-heptacosane $\left(C_{27}\right)$ and $n$-nonacosane $\left(\mathrm{C}_{2} 9\right)$ were $-34.2 \%$ and $-35.7 \%$, respectively (Table 1, Figure 1 ). These values are well within the range of those reported for C3 plants (Rieley et al., 1991, 1993, Collister et al., 1994b, Lichtfouse et al., 1994a). Also, observation of distributions together with isotope values strongly suggests a direct contribution of $\mathrm{C}_{3}$ plants waxes from previous $\mathrm{C}_{3}$ vegetation, although a contribution from soil organisms which biosynthesize those $n$-alkanes on $\mathrm{C}_{3}$ carbon is not excluded.

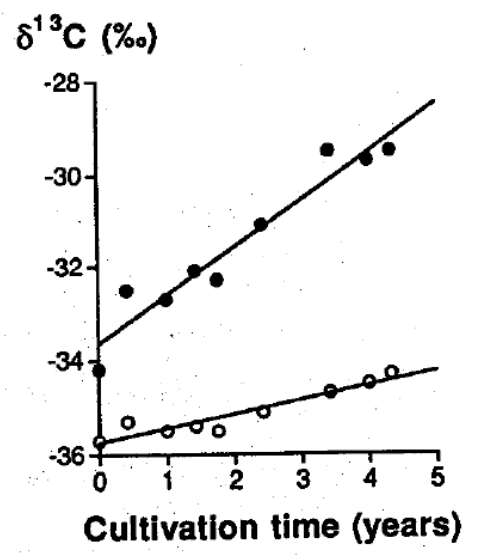

Fig. 1. Carbon isotope composition of soil $n$-alkanes versus time of maize cultivation. Note the higher isotopic increase of $n$-heptacosane $\left(\mathrm{C}_{27}\right)$ versus $n$-nonacosane $\left(\mathrm{C}_{29}\right)$. Linear regression gives $\delta_{27}=$ 1.028.time $-33.66(\mathrm{r}=0.96)$ and $\delta_{29}=0.300$.time $-35.74(\mathrm{r}=0.94)$. 
Table 1. Carbon isotope composition and relative abundance of selected $n$-alkanes from crop soils and maize leaf waxes.

\begin{tabular}{|c|c|c|c|}
\hline \multirow{2}{*}{$\begin{array}{l}\text { Cultivation } \\
\text { time (years) }\end{array}$} & \multicolumn{2}{|c|}{ Carbon number } & \multirow{2}{*}{$\mathrm{C}_{27} / \mathrm{C}_{29}$} \\
\hline & 27 & 29 & \\
\hline $0^{*}$ & -34.2 & -35.7 & 0.321 \\
\hline 0.42 & -32.5 & -35.3 & 0.332 \\
\hline 1.00 & -32.7 & -35.5 & 0.335 \\
\hline 1.42 & -32.1 & -35.4 & 0.355 \\
\hline 1.75 & -32.3 & -35.5 & 0.338 \\
\hline 2.42 & -31.1 & -35.1 & 0.378 \\
\hline 3.42 & -29.5 & -34.7 & 0.389 \\
\hline 4.00 & -29.7 & -34.5 & 0.403 \\
\hline 4.33 & -29.5 & -34.3 & 0.411 \\
\hline Maize & -19.1 & -18.4 & 0.916 \\
\hline
\end{tabular}

\section{Isotopic variations with increasing time of cultivation}

Isotope compositions of $n$-alkanes increased with cultivation time (Figure 1). Such variations are explained by the input of ${ }^{13} \mathrm{C}$ enriched carbon from maize into soil organic components. A direct input of maize leaf waxes into soil is possible since isotope compositions of maize $n$-alkanes are ${ }^{13} \mathrm{C}$ enriched: $-19.1 \%$ for $n$-heptacosane $\left(\mathrm{C}_{27}\right)$ and $-18.4 \%$ for $n$ nonacosane $\left(\mathrm{C}_{29}\right)$. Also the progressive addition of maize $n$-alkanes during cultivation should increase the isotope values of the soil $n$-alkanes, as shown in Fig. 1.

From the isotopic trends, it is obvious that the amount of maize-derived carbon in $n$-heptacosane $\left(\mathrm{C}_{27}\right)$ increased faster than in $n$-nonacosane $\left(\mathrm{C}_{29}\right)$. This difference can be quantitated by two means. Firstly, it can be assumed that isotopic trends versus cultivation time follow a linear law on a short time period, though this is probably not true for longer experiments. The slope calculated by linear regression, which is representative of the isotopic increase versus cultivation time for each component, is indeed much higher for $n$-heptacosane $\left(1.028 \%\right.$ o. $\left.\mathrm{yr}^{-1}\right)$ than for $n$-nonacosane $\left(0.300 \%\right.$ o. $\left.\mathrm{yr}^{-1}\right)$. Secondly, each soil $n$-alkane can be regarded as a mixture of two distinct isotopic sources: "C 3 " $n$-alkane from the initial soil and " $\mathrm{C}_{4}$ " $n$-alkane from maize waxes. At a given time of cultivation, the molar percentage of maizewax derived carbon $\mathrm{M}$ in each soil $n$-alkane can be calculated by

$M=100 .\left(\delta-\delta_{0}\right) /\left(\delta_{m}-\delta_{0}\right)$

$\delta$ : isotope composition of soil $n$-alkane at a given time of cultivation.

$\delta_{0}$ : isotope composition of soil $n$-alkane before maize cultivation (time $=0$ ).

$\delta_{\mathbf{m}}$ : isotope composition of $n$-alkane for maize waxes. 


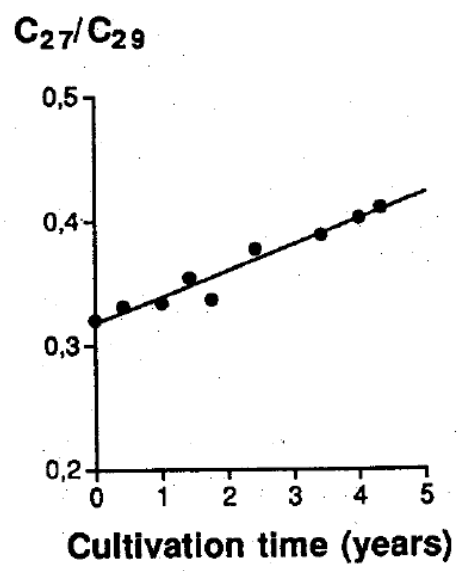

Fig. 2. $n$-Heptacosane $\left(\mathrm{C}_{27}\right) / n$-nonacosane $\left(\mathrm{C}_{29}\right)$ ratios in crop soils versus time of maize cultivation. Linear regression gives $\mathrm{C}_{27} / \mathrm{C}_{29}=0.021$.time $+0.319(\mathrm{r}=0.97)$.

Calculated $\mathrm{M}$ values after 5 crops of maize (4.33 yrs.) are $31.1 \%$ o for $n$-heptacosane and $8.1 \%$ o for $n$-nonacosane. Those values show again that $n$-heptacosane incorporated more maizederived carbon than $n$-nonacosane, probably via direct input of leaf waxes. Indeed, this hypothesis is strengthened by consideration of $n$-alkane relative abundances, as discussed below.

\section{n-Alkane ratios in soils and maize}

In order to get more insight on the mode of integration of maize carbon into crop soils, $n$-alkane relative abundances from maize leaves and soils were compared using $\mathrm{C}_{27} / \mathrm{C}_{29}$ ratios (Table1). Maize waxes had a much higher $\mathrm{C}_{27} / \mathrm{C}_{29}$ ratio (0.916) than did the soil before maize cultivation (0.321). It is thus expected that the $\mathrm{C}_{27} / \mathrm{C}_{2} 9$ ratio would increase with time of cultivation if a direct input were happening. $\mathrm{C}_{27} / \mathrm{C}_{2} 9$ ratios indeed showed a regular increase from 0.321 to 0.411 during 5 years of maize cropping (Fig. 2), thus demonstrating that soil $n$-alkanes were derived, at least partly, by direct input of maize leaf waxes. Further evidence is given by comparison of $\mathrm{C}_{27} / \mathrm{C}_{29}$ ratios with $\delta_{27}-\delta_{29}$ in soils (Figure 3). The correlation observed confirms that variations of isotopic differences between $n$-heptacosane and $n$-nonacosane resulted, at least partially, from a higher input of $n$-heptacosane from maize leaf waxes.

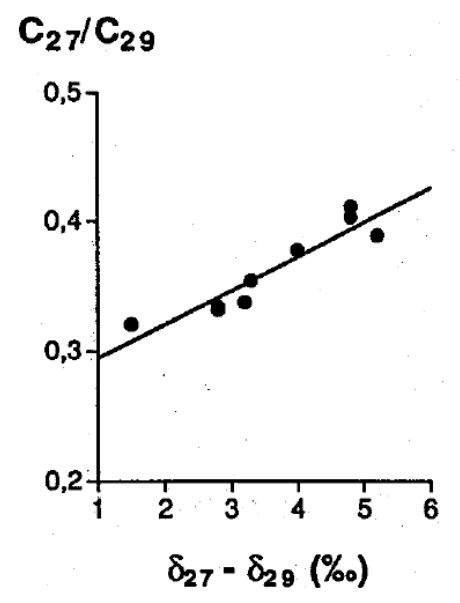

Fig. 3. Abundance ratios versus isotopic difference for $n$-heptacosane $\left(\mathrm{C}_{27}\right)$ and $n$-nonacosane $\left(\mathrm{C}_{29}\right)$ in maize crop soils. Linear regression gives $\delta_{27}-\delta_{29}=0.026 . \mathrm{C}_{27} / \mathrm{C}_{29}+0.269(\mathrm{r}=0.93)$. 


\section{CONCLUSION}

The contribution of plant waxes to crop soils has been evaluated by in situ labelling under natural conditions. A simple calculation has been used to evaluate the contribution of isotopically distinct sources within each $n$-alkane. Futhermore, soil $n$-alkanes have been shown to derive, at least partly, from the direct input of plant leaf $n$-alkanes. Isotope studies of other $n$ alkanes and organic fractions will be published elsewhere (Lichtfouse, 1994). Further work on soil alcohols and fatty acids is in progress.

Acknowledgements- We thank Profs. John hayes from Indiana University and Geoffrey Eglinton from Bristol University for helpful discussions. Dr. May Balabane from the Institut National de la Recherche Agronomique at Versailles is gratefully acknowledged for sampling assistance. We are indebted to Prof. James Maxwell from Bristol University for a critical review of this manuscript.

\section{REFERENCES}

Balesdent J., Mariotti A. and Guillet B. (1987) Natural ${ }^{13} \mathrm{C}$ abundance as a tracer for studies of soil organic matter dynamics. Soil Biol. Biochem. 19, 25-30.

Collister J. W., Lichtfouse E., Hieshima G. and Hayes J. M. (1994a) Partial resolution of sources of $n$ alkanes in the saline portion of the Parachute Creek Member, Green River Formation (Piceance Creek Basin, Colorado). Org. Geochem. 21, 645-659.

Collister J. W., Rieley G., Stern B., Eglinton G. and Fry B. (1994b) Compound-specific $\delta^{13}$ C analyses of leaf lipids from plants with differing carbon dioxide metabolisms. Org. Geochem. 21, 619-627.

Dinel H., Schnitzer M. and Mehuys G. R. (1990) Soil lipids: origin, nature, content, decomposition, and effect on soil physical properties. In Soil Biochemistry (Edited by Bollag J.-M. and Stotzky G.), pp. 397429. Marcel Dekker, New York.

Freeman K. H., Wakeham S. and Hayes J. M. (1994) Predictive isotopic biogeochemistry: hydrocarbons from anoxic marine basins. Org. Geochem. 21, 629-644.

Kolattukudy P. E. (Ed.) (1976) Chemistry and biochemistry of natural waxes. Elsevier, Amsterdam.

Lichtfouse E. (1994) Manuscript in preparation.

Lichtfouse E., Derenne S., Mariotti A. and Largeau C. (1994a) Possible algal origin of long chain odd $n$ alkanes in immature sediments as revealed by distributions and carbon isotope ratios. Org.Geochem. Submitted.

Lichtfouse E., Albrecht P., Béhar F. and Hayes J. M. (1994b) A molecular and isotopic study of the organic matter from the Paris Basin, France. Geochim. Cosmochim. Acta 58, 209-221.

Lichtfouse E. and Collister J. W. (1992) Tracing biogenic links of natural organic substances at the molecular level with stable carbon isotopes: $n$-alkanes and $n$-alkanoic acids from sediments. Tetrahedron Lett. 33, 8093-8094.

Lichtfouse E., Freeman K. H., Collister J. W. and Merritt D. A. (1991) Enhanced resolution of organic compounds from sediments by isotopic gas chromatography-combustion-mass spectrometry. $J$. Chromatogr. 585, 177-180.

Rieley G., Collier R. J., Jones D. M., Eglinton G., Eakin P. A. and Fallick A. E. (1991) Sources of sedimentary lipids deduced from stable carbon-isotope analyses of individual compounds. Nature 352, $425-426$.

Rieley G., Collister J. W., Stern B. and Eglinton G. (1993) Gas chromatography-Isotope Ratio Mass Spectrometry of leaf wax $n$-alkanes from plants of differing carbon dioxide metabolisms. Rapid Commun. Mass Spectrom. 7, 488-491.

Spooner N., Rieley G., Collister J. W., Lander M., Cranwell P. A. and J. R. Maxwell (1994) Stable carbon isotopic correlation of individual biolipids in aquatic organisms and a lake bottom sediment. Org. Geochem. 21, 823-827. 